\title{
Impacts of land use change in soil carbon and nitrogen in a Mediterranean agricultural area (Southern Spain)
}

\author{
L. Parras-Alcántara, M. Martín-Carrillo, and B. Lozano-García \\ Department of Agricultural Chemistry and Soil Science, Faculty of Science, Agrifood Campus of International Excellence, \\ ceiA3, University of Cordoba, 14071 Cordoba, Spain
}

Correspondence to: L. Parras-Alcántara (qe1paall@uco.es)

Received: 27 December 2012 - Published in Solid Earth Discuss.: 22 February 2013

Revised: 20 April 2013 - Accepted: 22 April 2013 - Published: 14 May 2013

\begin{abstract}
The agricultural Mediterranean areas are dedicated to arable crops (AC), but in the last decades, a significant number of $\mathrm{AC}$ has led to a land use change (LUC) to olive grove $(\mathrm{OG})$ and vineyards $(\mathrm{V})$. A field study was conducted to determine the long-term effects (46 years) of LUC (AC by OG and V) and to determine soil organic carbon (SOC), total nitrogen (TN), $\mathrm{C}: \mathrm{N}$ ratio and their stratification across the soil entire profile, in Montilla-Moriles denomination of origin (D.O.), in Calcic-Chromic Luvisols (LVcc/cr), an area under semiarid Mediterranean conditions. The experimental design consisted of studying the LUC on one farm between 1965 and 2011. Originally, only AC was farmed in 1965, but OG and V were farmed up to now (2011). This LUC principally affected the horizon thickness, texture, bulk density, $\mathrm{pH}$, organic matter, organic carbon, total nitrogen and $\mathrm{C}: \mathrm{N}$ ratio. The LUC had a negative impact in the soil, affecting the SOC and TN stocks. The conversion from $\mathrm{AC}$ to $\mathrm{V}$ and $\mathrm{OG}$ involved the loss of the SOC stock $(52.7 \%$ and $64.9 \%$ to $\mathrm{V}$ and OG respectively) and the loss of the TN stock (42.6\% and $38.1 \%$ to $\mathrm{V}$ and OG respectively). With respect to the stratification ratios (SRs), the effects were opposite; 46 years after LUC increased the SRs (in V and OG) of $\mathrm{SOC}, \mathrm{TN}$ and $\mathrm{C}: \mathrm{N}$ ratio.
\end{abstract}

\section{Introduction}

Soils play a key role in the carbon (C) geochemical cycle because they can either emit large quantities of $\mathrm{CO}_{2}$ or on the contrary they can act as a store for C (Smith et al., 2000). Agriculture and forestry can contribute to $\mathrm{C}$ sequestration through photosynthesis and the incorporation of $\mathrm{C}$ into car- bohydrates (González-Sánchez et al., 2012). Crops capture $\mathrm{CO}_{2}$ from the atmosphere during photosynthesis into soil organic matter (SOM). Degradation of SOM by microbial processes may be limited by aggregate stability, adsorption by clays or the formation of organo-mineral complexes (Johnson et al., 2007; Lal, 1997). Soil management is one of the best tools for climate change mitigation and adaptation (Lal et al., 2011). Several authors have proposed introducing soil management techniques that combine a restriction on tillage (Corral-Fernández et al., 2013) and the addition of organic residues (Lozano-García et al., 2011; Lozano-García and Parras-Alcántara 2013) to improve soil quality and favor $\mathrm{C}$ sequestration into soils.

Carbon sequestration is defined as a net additional transfer of $\mathrm{C}$ from atmospheric $\mathrm{CO}_{2}$ to soils after a change in land management (Powlson et al., 2011). Therefore, C sequestration into soils is one of the most important ecosystem services because of its role in climate regulation (IPCC, 2007). Intensification of agriculture and/or transformation of conventional tillage (CT) practices, may cause enormous losses of soil organic carbon (SOC), thus inducing an increase in soil erosion and a breakage of soil structure (Melero et al., 2009). Land use change (LUC) is considered the second greatest cause of $\mathrm{C}$ emissions after fuel consumption (Watson et al., 2000). LUC has contributed to soil degradation and soil loss, leading to a decrease in soil C storage worldwide (Eaton et al., 2008), and even more intensely in the Mediterranean areas during the last few decades (Cerdà et al., 2010). Longterm experimental studies have confirmed that SOC is highly sensitive to LUC (Smith, 2008). Thus, even a relatively small increase or decrease in soil carbon content due to changes in land use or management practices may result in a significant 
net exchange of $\mathrm{C}$ between the soil $\mathrm{C}$ pool and the atmosphere (Houghton, 2003). Recently, it has been shown that soil erosion by water and/or tillage has a significant impact on this large pool of SOC (Lal, 2003; Van Oost et al., 2005; Van Hemelryck et al., 2011).

Regional-scale information about $\mathrm{C}$ stocks and the relationship between $\mathrm{C}$ reservoirs and edaphic factors could be relevant to determine LUC that is of interest in evaluating gains and losses of SOC (Novara et al., 2012). Climate, use and management are highly influential in the $\mathrm{C}$ variability in Spanish soils (Muñoz-Rojas et al., 2012; Rodríguez-Murillo et al., 2001; Ruiz et al., 2012), mainly in semiarid regions, characterized by low levels of SOM content $\left(\sim 10 \mathrm{~g} \mathrm{~kg}^{-1}\right)$ (Acosta-Martínez et al., 2003).

The soil $\mathrm{C}: \mathrm{N}$ ratio is a soil fertility indicator due to the close relationship between SOC and total nitrogen (TN). The soil $\mathrm{C}: \mathrm{N}$ ratio is often influenced by many factors such as climate (Miller et al., 2004), soil conditions (Ouédraogo et al., 2006; Yamashita et al., 2006), vegetation types (Diekow et al., 2005; Puget and Lal, 2005), and agricultural management practices (Zhang et al., 2009).

The concept of using the stratification ratio (SR) as a soil quality indicator is based on the influence of the SOC surface level in erosion control, water infiltration and nutrient conservation (Franzluebbers, 2002). High SR of SOC and TN pools reflect relatively undisturbed soil with high soil quality of the surface layer. The increase of SR can be related to rate and amount of SOC sequestration (Franzluebbers, 2002).

Soil depth has a decisive influence on SOC stocks (Grüneberg et al., 2010). Some authors have evaluated the SOC content in soil surface (restricted to the upper 15-30 or $50 \mathrm{~cm}$ ), and a few studies have included a deeper section of soil cover (Conant and Paustian, 2002), although vertical processes have a significant impact on SOC variability (VandenBygaart, 2006). Sombrero and de Benito (2010) noted that to evaluate and compare SOC storage, complete profile is necessary. According to Lorenz and Lal (2005) in temperate climates, large amounts of SOC may be stored in subsoil horizons below $30 \mathrm{~cm}$ deep. This is essential in studies about the effects of LUC on SOC because the SOC can be transported to a deeper soil horizon, contributing to the subsoil C storage (Lorenz and Lal, 2005). Vertical distribution is one of the features of the organic $\mathrm{C}$ store that is not clearly understood together with the relationships with climate and vegetation (Jobbágy and Jackson, 2000). In the last decades, a significant number of arable crops (AC) have been transformed into olive grove cultivations $(\mathrm{OG})$ or vineyards $(\mathrm{V})$ in Montilla-Moriles denomination of origin (D.O.) in Córdoba (South Spain). LUCs in this area have been motivated by subsidies and better olive oil and wine prices.

Very few reports have compared the effect of transformation from $\mathrm{AC}$ to $\mathrm{OG}$ and $\mathrm{V}$ on $\mathrm{SOC}$ and $\mathrm{TN}$ storages even on soil quality for the long term in the entire soil profiles. In this context, the objectives of this work are (i) to determine the SOC content in the soil; (ii) to study SOC vertical distri-

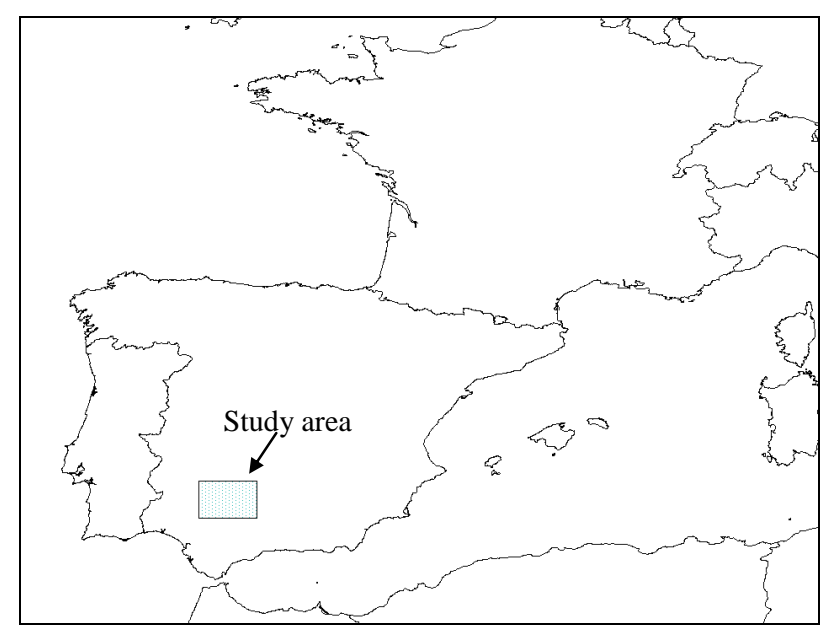

Fig. 1. Study area.

bution; (iii) to analyze the accumulation and SR of SOC, TN and $\mathrm{C}: \mathrm{N}$ ratio in Calcic-Chromic Luvisols (LVcc/cr) (IUSSISRIC-FAO, 2006) in AC affected by LUC for the long term (46 years) in conventional tillage.

\section{Material and methods}

\subsection{Site description and experimental design}

The study area comprises 33607 ha located in MontillaMoriles D.O., Córdoba $\left(37^{\circ} 38^{\prime}-29^{\prime} \mathrm{N}, 4^{\circ} 45^{\prime}-31^{\prime} \mathrm{W}\right.$, 432 m.a.s.l.) (Fig. 1). Montilla is the first production center of Montilla-Moriles wines. This D.O. produced wines with the grapes of the Pedro Ximénez variety.

The parent material is Triassic gypsiferous marls. The relief is smooth with slopes ranging from $3 \%$ to $8 \%$. According to IUSS Working Group WRB (2006), the most abundant soils are Luvisol (LV) and Cambisol (CM), locally known as alberos and albarizas, respectively. Fluvisol (FL), Regosol (RG) and Vertisol (VR) are also present. These substrates correspond to the upper limit of the Pliocene period (Andalusian subperiod), which are characterized by the presence of white marls (argyle-containing limestone) typical of the Guadalquivir Basin. These are soft soils owing to the presence of limestone, with very high permeability and high water retention (essential for lands with frequent dry spells).

The Montilla-Moriles D.O. is characterized by cold winters and warm, dry summers with extreme measured temperatures ranging from $-2.0^{\circ} \mathrm{C}$ to $37.8^{\circ} \mathrm{C}$ and an average annual rainfall of $602.7 \mathrm{~mm}$. The moisture regime is dry Mediterranean with continental features due to elevation and location.

An unirrigated farm (100 ha) in Montilla-Moriles D.O. cultivated under conventional tillage (CT) was selected for study in 1965. The soil was a Calcic-Chromic Luvisol (LV 
cc-cr) (classified according to IUSS-ISRIC-FAO, 2006). In 1966, the study farm (100 ha) was divided into three plots with three different uses (AC, OG and $\mathrm{V}$ respectively). The preliminary analyses were realized in 1965 for $\mathrm{AC}$ (AC1), and the second analyses were realized in 2011 for $\mathrm{AC}$ (AC2), OG and V. In 2011, 22 samples were collected (7 for AC2, 5 for $\mathrm{V}$ and 10 for OG) (Figs. 2 and 3). In all cases (AC1, $\mathrm{AC} 2$, OG and $\mathrm{V}$ ) were collected soil entire profiles. Table 1 summarizes the land use class and Table 2 summarizes the principal soil properties for the study.

\subsection{Soil sampling and analytical methods}

Soil samples were dried at a constant room temperature $\left(25^{\circ} \mathrm{C}\right)$ and sieved $(2 \mathrm{~mm})$ to eliminate coarse soil particles. Soil $\mathrm{pH}$ was measured in an aqueous soil extract in deionized water (1:2.5 soil:water) (Guitián and Carballas, 1976). Prior to determining the particle size distribution, the samples were treated with $\mathrm{H}_{2} \mathrm{O}_{2}(6 \%)$ to remove organic matter. The fraction of particles with a diameter greater than $2 \mathrm{~mm}$ was determined by wet sieving. Particles measuring $<2 \mathrm{~mm}$ were classified according to USDA standards (USDA, 2004). Soil bulk density was measured by the core method (Blake and Hartge, 1986) using a $3.0 \mathrm{~cm}$-diameter and $10.0 \mathrm{~cm}$-deep core. The distribution of soil particle size was analyzed using the Robinson pipette system (USDA, 2004). SOC were determined by wet oxidation with dichromate according to the Walkley and Black system (Walkley and Black, 1934). TN was determined using the Kjeldahl method (Bremner, 1996). The soil C: N ratio was calculated by dividing SOC\% by $\mathrm{TN} \%$. The SOC stock $\left(\mathrm{Mg} \mathrm{ha}^{-1}\right)$ was calculated for each horizon according to Wang and Dalal (2006) as follows:

SOC stock $=$ SOC concentration $\times \mathrm{BD} \times d \times\left(1-\delta_{2} \mathrm{~mm} \%\right) \times 0.1$

where $d$ is the thickness of the soil layer $(\mathrm{cm}), \delta_{2} \mathrm{~mm}$ is the fractional percentage (\%) of $>2 \mathrm{~mm}$ gravel in the soil, and $\mathrm{BD}$ is the bulk density $\left(\mathrm{Mg} \mathrm{m}^{-3}\right)$. The $\mathrm{TN}$ stock $\left(\mathrm{Mg} \mathrm{ha}^{-1}\right)$ was also calculated.

The SRs were calculated from SOC, TN and the $\mathrm{C}: \mathrm{N}$ ratio data following Franzluebbers (2002). The SR is defined as a soil property on the soil surface divided by the same property at a lower depth. In this study, we defined four SRs ([SR1] for Ap/Ap2-Bt, [SR2] for Ap/Bt-B-Ck, [SR3] for Ap/C-Bt-C and [SR4] for Ap/C2-C-Ck).

The statistical analysis was performed using SPSS Inc. (2004). The statistical significance of the differences in the variables between land use practices was tested using the Anderson-Darling test at each horizon or a combination of horizons for each soil type. Differences with $p<0.05$ were considered statistically significant.

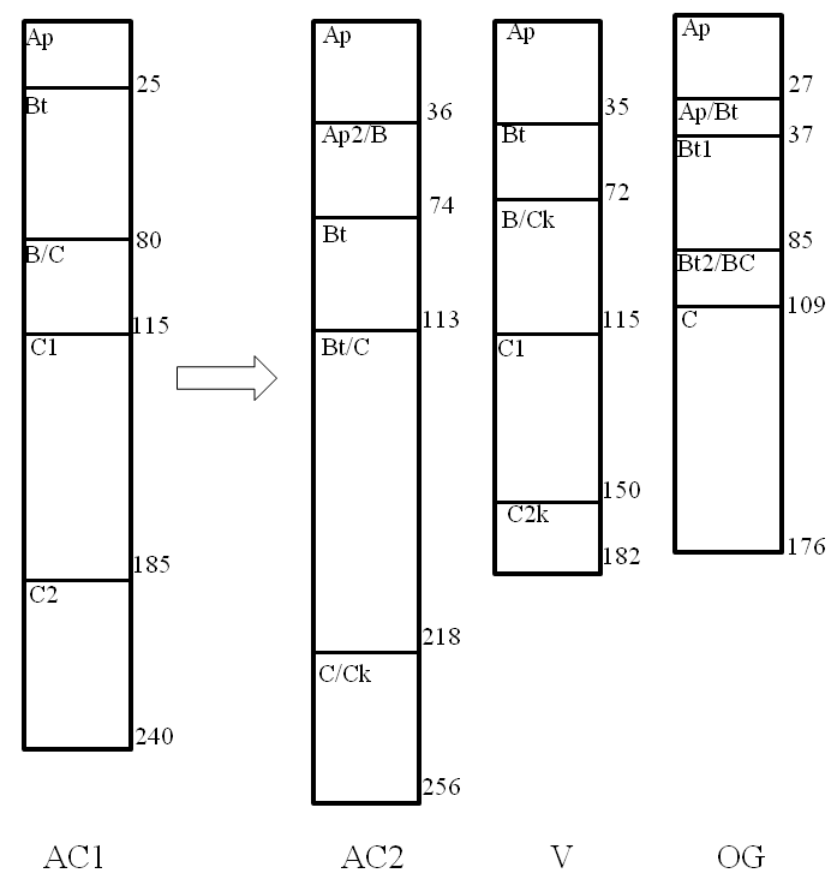

Fig. 2. Soil entire profiles. AC1 (arable crop in 1965), affect by land use conversion (LUC) to AC2 (arable crop), V (vineyard) and OG (olive groves). The LUC was in 1965 (AC1), after 41 years, AC2, V and OG. (Numbers are soil thickness).

\section{Results and discussion}

\subsection{Soil properties}

The studied soil is classified as LVcc/cr (IUSS-ISRIC-FAO, 2006). The principal characteristic of these soils is high clay content in the Bt horizon due to migration of clay particles (Table 2). Luvisols are well-developed fertile soils that are suitable for a broad variety of typically Mediterranean uses such as cereals, fruit trees, olives and vineyards (Zdruli et al., 2011).

With respect to the soil thickness, there were no significant differences $(p<0.05)$ in time (46 years) for the same land use ( $\mathrm{AC} 1$ and $\mathrm{AC} 2$ ), however, during the LUC from $\mathrm{AC} 1$ to $\mathrm{V}$ and OG the soil thickness decreased, ranging from $240 \mathrm{~cm}$ in $\mathrm{AC} 1$ to $182 \mathrm{~cm}$ and $176 \mathrm{~cm}$ in $\mathrm{V}$ and OG, respectively (Table 2 and Fig. 2). This thickness reduction for $\mathrm{V}$ and $\mathrm{OG}$ was caused by the slope steepness, length, topographic curvature and relative position (different positions in the study farm could be explained in part by these thickness reductions). In this line, McKenzie and Austin (1993) obtained similar results in Australian soils. By contrast, Bakker et al. (2005) in Lesvos-Greece for LUC (AC to V and pastures to OG) between 1956 and 1996 justified this thickness reduction by associating it with new mechanized equipment (heavy machinery) and water erosion. These causes could be other reasons to justify the thickness reduction in the studied soils. 
Table 1. Land use categories and class in Montilla-Moriles DO.

\begin{tabular}{lllll}
\hline Land use & Abbreviation & Year & & \multicolumn{1}{c}{ Characteristics } \\
\hline $\begin{array}{l}\text { Arable } \\
\text { crop }\end{array}$ & AC1 & 1965 & $\begin{array}{l}\text { Rudimentary } \\
\text { machinery } \\
\text { Minimum } \\
\text { tillage }\end{array}$ & $\begin{array}{l}\text { Systems using animal power (plow with } \\
\text { mules) with lightweight reversible plows. } \\
\text { Non-mineral fertilization or pesticides. }\end{array}$ \\
\hline $\begin{array}{l}\text { Arable } \\
\text { crop }\end{array}$ & AC2 & 2006 & $\begin{array}{l}\text { Heavy } \\
\text { machinery }\end{array}$ & $\begin{array}{l}\text { Winter crop rotation with annual wheat and } \\
\text { barley. Mineral fertilization or pesticides. }\end{array}$ \\
$\begin{array}{l}\text { Vineyard } \\
\text { V }\end{array}$ & V & & $\begin{array}{l}\text { News } \\
\text { mechanized } \\
\text { equipment } \\
\text { Conventional } \\
\text { tillage }\end{array}$ & $\begin{array}{l}\text { Vineyard planted on traditional espalier. } \\
\text { Mineral fertilization or pesticides. Three or } \\
\text { five chisel passes a year to a depth of 15 to } \\
\text { 20 cm from early spring to early autumn. }\end{array}$ \\
$\begin{array}{l}\text { Olive } \\
\text { groves }\end{array}$ & OG & 2006 & $\begin{array}{l}\text { Annual passes with disk harrow and } \\
\text { cultivator in the spring, followed by a tine } \\
\text { harrow in the summer. Mineral fertilization, } \\
\text { pesticides and weed control with residual } \\
\text { herbicides. }\end{array}$ \\
& & & &
\end{tabular}

Table 2. Basic physical and chemical properties for Calcic/Chromic Luvisol in Arable land (wheat and barley annual rotation), Vineyard and Olive groves. AC1: Arable crop 1965, AC2: Arable crop 2006, V: Vineyard 2006, OG: Olive groves 2006. Data are means \pm SD $(n=5,7$, $5,10)$. Hor. $=$ Horizon type.

\begin{tabular}{|c|c|c|c|c|c|c|c|c|c|c|c|c|c|c|c|}
\hline Soil & Hor. & $\begin{array}{r}\text { Depth } \\
\mathrm{cm}\end{array}$ & $\begin{array}{r}\text { Thickness } \\
\mathrm{cm}\end{array}$ & $\begin{array}{r}\text { Gravel } \\
\%\end{array}$ & $\begin{array}{r}\text { Sand } \\
\%\end{array}$ & $\begin{array}{r}\text { Silt } \\
\%\end{array}$ & $\begin{array}{r}\text { Clay } \\
\%\end{array}$ & $\begin{array}{r}\text { Bulk } \\
\text { density } \\
\mathrm{Mg} \mathrm{m}^{-3}\end{array}$ & $\begin{array}{r}\mathrm{pH} \\
\mathrm{H}_{2} \mathrm{O}\end{array}$ & $\begin{array}{r}\mathrm{OM} \\
\mathrm{g} \mathrm{kg}^{-1}\end{array}$ & $\begin{array}{r}\mathrm{SOC} \\
\mathrm{g} \mathrm{kg}^{-1}\end{array}$ & $\begin{array}{r}\text { Total } \\
\mathrm{SOC} \\
\mathrm{g} \mathrm{kg}^{-1}\end{array}$ & $\begin{array}{r}\mathrm{TN} \\
\mathrm{g} \mathrm{kg}^{-1}\end{array}$ & $\begin{array}{r}\text { Total } \\
\mathrm{TN} \\
\mathrm{g} \mathrm{kg}^{-1}\end{array}$ & $\mathrm{C} / \mathrm{N}$ \\
\hline \multirow{7}{*}{$\begin{array}{l}\mathrm{AC} 1 \\
n=5^{* *}\end{array}$} & $\mathrm{Ap}$ & $0-25$ & $25 \pm 3.1$ & $1.5 \pm 0.8^{*}$ & $29.8 \pm 2.2$ & $13.3 \pm 1.8$ & $56.9 \pm 2.9$ & $1.43 \pm 0.21$ & $7.1 \pm 0.3$ & $19.0 \pm 1.1$ & $11.1 \pm 1.2$ & \multirow{6}{*}{44.9} & $0.89 \pm 0.02$ & \multirow{5}{*}{3.55} & 12.47 \\
\hline & $\mathrm{Bt}$ & $25-80$ & $55 \pm 4.2$ & $0.9 \pm 0.4 *$ & $27.1 \pm 2.8$ & $10.8 \pm 3.4$ & $62.1 \pm 2.1$ & $1.53 \pm 0.12$ & $7.2 \pm 0.7$ & $17.4 \pm 1.0$ & $10.1 \pm 0.5$ & & $0.75 \pm 0.06$ & & 13.47 \\
\hline & $\mathrm{B} / \mathrm{C}$ & $80-115$ & $35 \pm 3.3$ & $1.3 \pm 0.5^{*}$ & $21.5 \pm 2.1$ & $25.7 \pm 2.7$ & $52.8 \pm 3.1$ & $1.58 \pm 0.31$ & $7.7 \pm 0.4$ & $15.8 \pm 0.7$ & $9.2 \pm 0.2$ & & $0.71 \pm 0.02$ & & 12.96 \\
\hline & $\mathrm{C} 1$ & $115-185$ & $70 \pm 6.3$ & $1.2 \pm 0.3^{*}$ & $25.4 \pm 3.2$ & $30.7 \pm 4.1$ & $43.9 \pm 6.2$ & $1.69 \pm 0.21$ & $7.6 \pm 0.8$ & $13.8 \pm 0.6$ & $8.1 \pm 0.6$ & & $0.67 \pm 0.17$ & & 12.09 \\
\hline & $\mathrm{C} 2$ & $185-240$ & $55 \pm 4.1$ & $2.4 \pm 1.1$ & $29.9 \pm 5.3$ & $33.6 \pm 3.2$ & $36.5 \pm 3.9$ & $1.74 \pm 0.34$ & $7.7 \pm 0.3$ & $11.0 \pm 0.8$ & $6.4 \pm 0.5$ & & $0.53 \pm 0.09$ & & 12.07 \\
\hline & Ap & $0-36$ & $36 \pm 2.2$ & $3.3 \pm 0.9$ & $32.8 \pm 3.1$ & $41.6 \pm 3.4$ & $25.6 \pm 3.2$ & $1.43 \pm 0.16$ & $7.6 \pm 0.9$ & $16.2 \pm 2.4$ & $9.5 \pm 1.2$ & & $1.53 \pm 0.06$ & \multirow{5}{*}{3.99} & 7.97 \\
\hline & Ap2/B & $36-74$ & $38 \pm 3.5$ & $3.1 \pm 0.5$ & $28.5 \pm 2.7$ & $32.2 \pm 1.7$ & $39.3 \pm 2.8$ & $1.45 \pm 0.34$ & $7.5 \pm 0.4$ & $10.7 \pm 1.7$ & $6.3 \pm 0.6$ & \multirow{4}{*}{31.8} & $0.86 \pm 0.03$ & & 7.32 \\
\hline \multirow{3}{*}{$\begin{array}{l}\mathrm{AC} 2 \\
n=7^{* *}\end{array}$} & $\mathrm{Bt}$ & $74-113$ & $39 \pm 3.6$ & $2.4 \pm 1.5$ & $35.1 \pm 4.3$ & $28.3 \pm 4.2$ & $36.6 \pm 4.6$ & $1.43 \pm 0.11$ & $7.6 \pm 0.6$ & $13.1 \pm 0.8$ & $7.7 \pm 0.3$ & & $0.98 \pm 0.02$ & & 7.86 \\
\hline & $\mathrm{Bt} / \mathrm{C}$ & $113-218$ & $105 \pm 6.2$ & $2.3 \pm 0.8$ & $29.9 \pm 2.6$ & $42.2 \pm 4.8$ & $27.9 \pm 3.7$ & $1.47 \pm 0.36$ & $7.9 \pm 0.4$ & $9.5 \pm 1.6$ & $5.6 \pm 0.5$ & & $0.62 \pm 0.05$ & & 9.03 \\
\hline & $\mathrm{C} / \mathrm{Ck}$ & $218-256$ & $38 \pm 2.1$ & $2.9 \pm 0.9$ & $45.4 \pm 9.8$ & $33.6 \pm 2.6$ & $21.0 \pm 1.6$ & $1.57 \pm 0.48$ & $7.8 \pm 0.3$ & $4.6 \pm 0.9$ & $2.7 \pm 0.5$ & & $0.35 \pm 0.06$ & & 7.71 \\
\hline \multirow{6}{*}{$\begin{array}{l}\mathrm{V} \\
n=5^{* *}\end{array}$} & Ap & $0-35$ & $35 \pm 1.8$ & $3.3 \pm 1.1$ & $39.3 \pm 3.4$ & $46.4 \pm 3.1$ & $14.3 \pm 2.1$ & $1.42 \pm 0.31$ & $8.1 \pm 0.7$ & $21.6 \pm 1.2$ & $12.6 \pm 0.9$ & \multirow{5}{*}{29.5} & $1.03 \pm 0.05$ & \multirow{5}{*}{2.81} & 12.23 \\
\hline & $\mathrm{Bt}$ & $35-72$ & $37 \pm 2.9$ & $3.0 \pm 0.9$ & $42.0 \pm 2.7$ & $34.0 \pm 2.9$ & $24.0 \pm 3.1$ & $1.47 \pm 0.26$ & $8.1 \pm 0.2$ & $10.5 \pm 0.6$ & $6.1 \pm 0.5$ & & $0.63 \pm 0.03$ & & 9.68 \\
\hline & $\mathrm{B} / \mathrm{Ck}$ & $72-115$ & $43 \pm 6.5$ & $1.8 \pm 0.6^{*}$ & $40.5 \pm 5.1$ & $40.1 \pm 3.9$ & $19.4 \pm 2.3$ & $1.51 \pm 0.21$ & $8.3 \pm 0.6$ & $7.5 \pm 0.3$ & $4.4 \pm 0.2$ & & $0.55 \pm 0.01$ & & 8.00 \\
\hline & $\mathrm{C} 1$ & $115-150$ & $35 \pm 2.4$ & $1.4 \pm 0.3^{*}$ & $43.4 \pm 4.8$ & $33.8 \pm 4.5$ & $22.8 \pm 3.9$ & $1.51 \pm 0.14$ & $8.3 \pm 0.8$ & $7.0 \pm 0.6$ & $4.1 \pm 0.4$ & & $0.33 \pm 0.06$ & & 12.42 \\
\hline & $\mathrm{C} 2 \mathrm{k}$ & $150-182$ & $32 \pm 3.2$ & $2.3 \pm 0.7$ & $30.6 \pm 3.7$ & $41.6 \pm 5.7$ & $27.8 \pm 3.4$ & $1.51 \pm 0.22$ & $8.4 \pm 0.1$ & $3.9 \pm 0.4$ & $2.3 \pm 0.3$ & & $0.27 \pm 0.03$ & & 8.52 \\
\hline & Ap & $0-27$ & $27 \pm 3.9$ & $2.3 \pm 0.3$ & $29.4 \pm 2.4$ & $14.9 \pm 6.7$ & $38.5 \pm 1.2$ & $1.25 \pm 0.24$ & $7.9 \pm 0.5$ & $17.3 \pm 2.4$ & $10.1 \pm 1.1$ & \multirow{5}{*}{28.8} & $1.07 \pm 0.06$ & \multirow{5}{*}{3.84} & 9.44 \\
\hline \multirow{4}{*}{$\begin{array}{l}\text { OG } \\
n=10^{* *}\end{array}$} & $\mathrm{Ap} / \mathrm{Bt}$ & $27-37$ & $10 \pm 1.2$ & $1.5 \pm 0.5^{*}$ & $32.1 \pm 3.7$ & $34.7 \pm 2.5$ & $33.2 \pm 2.5$ & $1.39 \pm 0.32$ & $7.9 \pm 0.7$ & $11.1 \pm 1.7$ & $6.5 \pm 0.6$ & & $0.87 \pm 0.03$ & & 7.47 \\
\hline & Bt1 & $37-85$ & $48 \pm 9.4$ & $0.7 \pm 0.4^{*}$ & $30.1 \pm 6.2$ & $26.4 \pm 4.6$ & $45.3 \pm 6.3$ & $1.29 \pm 0.12$ & $8.0 \pm 0.6$ & $8.7 \pm 0.2$ & $5.1 \pm 0.5$ & & $0.85 \pm 0.04$ & & 6.00 \\
\hline & Bt $2 / B C$ & 85-109 & $24 \pm 2.6$ & $1.1 \pm 0.3^{*}$ & $22.2 \pm 5.4$ & $31.3 \pm 5.4$ & $46.5 \pm 6.1$ & $1.31 \pm 0.17$ & $8.0 \pm 0.1$ & $6.3 \pm 0.6$ & $3.7 \pm 0.6$ & & $0.53 \pm 0.07$ & & 6.98 \\
\hline & $\mathrm{C}$ & $109-176$ & $67 \pm 4.2$ & $1.2 \pm 0.4^{*}$ & $29.1 \pm 3.6$ & $32.8 \pm 3.8$ & $38.1 \pm 3.4$ & $1.33 \pm 0.21$ & $8.1 \pm 0.1$ & $5.7 \pm 0.3$ & $3.4 \pm 0.4$ & & $0.52 \pm 0.06$ & & 6.54 \\
\hline
\end{tabular}

*No significant data for Stratification Ratio (SR).

* Size sampling.

These soils are characterized by low OM concentrations in depth, especially in V and OG; this can be explained by the soil textures (sandy soils). González and Candás (2004) found that the formation of OM and mineral aggregates diminishes in the surface horizons of sandy soils, thus favoring high levels of transformed OM, which explain the low OM concentrations at greater depths in the soil studied (Table 2). In addition, Gallardo et al. (2000) explain that the low OM values are explained partly by the semiarid Mediterranean conditions, which are accentuated in Europe's southern soils.

\subsection{Soil organic carbon (SOC), Total Nitrogen (TN) and $\mathrm{C}: \mathrm{N}$ ratio}

In all cases ( $\mathrm{AC} 1, \mathrm{~V}$ and $\mathrm{OG})$, the SOC concentration decreased in depth, with the exception of $\mathrm{AC} 2$, which is caused by the high OM concentration in Bt (Table 2).

According to the study of Hernanz et al. (2009) on rainfed crops of Mediterranean semiarid regions, soils present a low OC content due to the high mineralization of the OM and the absence of harvest residues after periods of drought. On the contrary, soils with tree coverage show an increase in $\mathrm{C}$ and nitrogen (N) (Albretch and Kandji, 2003); we obtained similar results in topsoil, in $\mathrm{V}$ and $\mathrm{OG}$. The SOC found in AC1 


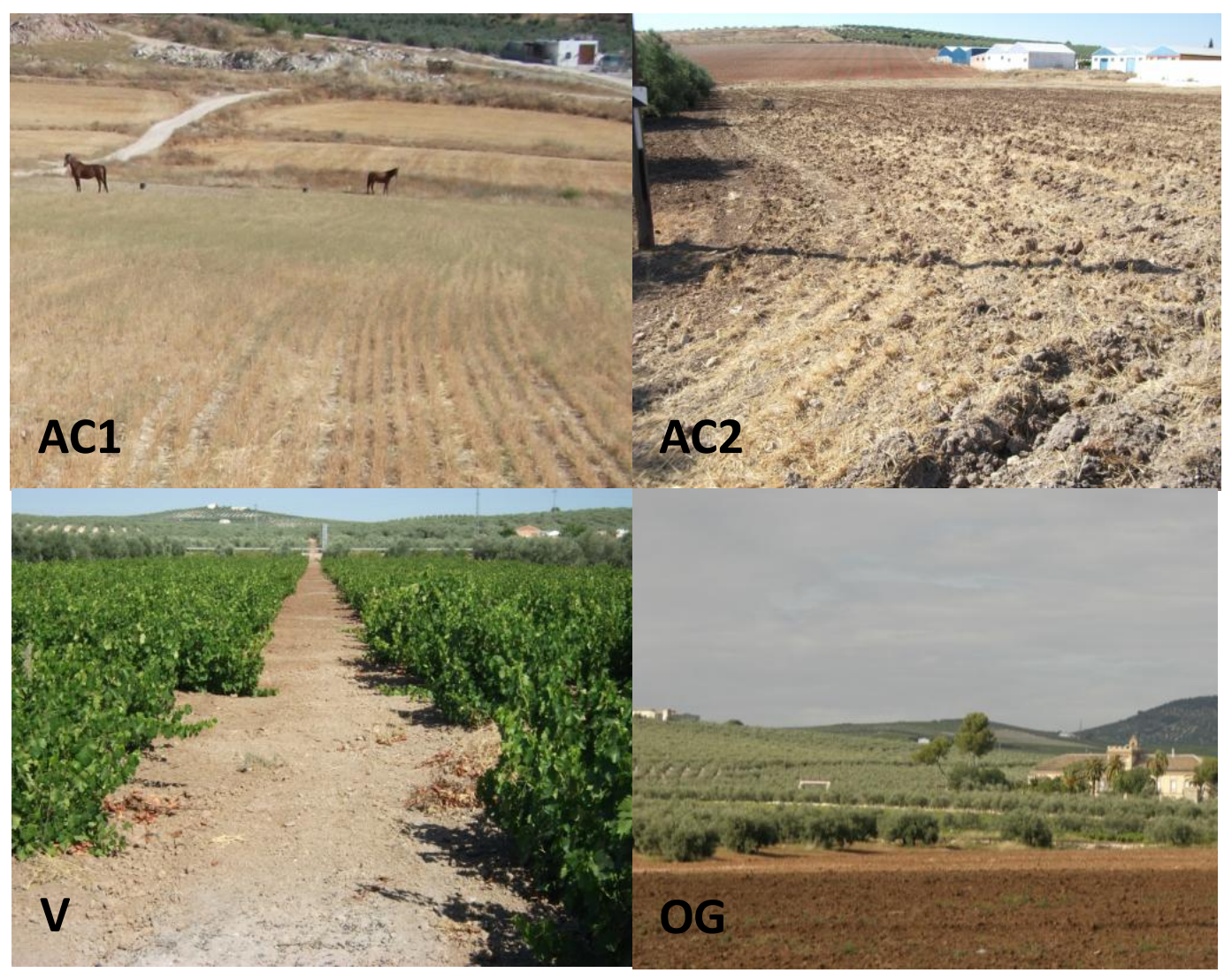

Fig. 3. Montilla-Moriles D.O. (AC1) Arable crop, systems using animal power (plow with mules) with lightweight reversible plows. (AC2) Arable crop, heavy machinery - news mechanized equipment, (V) Vineyard modern, (OG) Olive groves.

was greater $\left(11.1 \pm 1.2 \mathrm{~g} \mathrm{~kg}^{-1}\right)$ than that estimated by Don et al. (2007), who established $10 \mathrm{~g} \mathrm{~kg}^{-1}$ for soils with cereal crops in Spain, which must be caused by the accumulation of litter and dead roots in the topsoil.

$\mathrm{TN}$ and the $\mathrm{C}: \mathrm{N}$ ratio tended to decrease with depth, with the exception of AC2. Sá et al. (2001) observed an increase in the soil $\mathrm{C}: \mathrm{N}$ ratio in depth (AC2), which may be attributed to high $\mathrm{C}: \mathrm{N}$ soluble organic compounds leaching into deeper layers (Diekow et al., 2005). For OG, this decrease may be a result of the increased soil clay content with depth (Table 2 ). Higher clay content is often associated with more decomposed $\mathrm{OM}$ with a lower $\mathrm{C}: \mathrm{N}$ ratio (Puget and Lal 2005; Yamashita et al., 2006). In the case of $\mathrm{AC} 1$ and $\mathrm{V}$, crop residues could favour a higher soil $\mathrm{C}: \mathrm{N}$ ratio (Puget and Lal, 2005). Additionally, residue retention can increase the proportion of SOC (Xu et al., 2011) with a lower decomposition degree and higher $\mathrm{C}: \mathrm{N}$ ratio (Yamashita et al., 2006). Under AC2, the incorporation of residues into the soil can be uniformly distributed with depths up to $20 \mathrm{~cm}$, or more than $20 \mathrm{~cm}$ (Sá and Lal, 2009; Wright et al., 2007). In contrast, under AC1 and $\mathrm{V}$ the input of residues is restricted to the topsoil. Consequently, the soil $\mathrm{C}: \mathrm{N}$ ratio may be stratified to show a declining trend with depths in the upper soil profile. The $\mathrm{C}: \mathrm{N}$ ratio in the surface soil was higher than in deeper soil horizons, especially in $\mathrm{V}$ (12.23:1) and OG (9.44:1), thus indicating high resolution and separation rates. Lal et al. (1995) indicate that $\mathrm{C}: \mathrm{N}$ ratios are low during resolution and separation times. Brady and Weil (2008) show that $\mathrm{C}: \mathrm{N}$ ratios vary between $8: 1$ and $15: 1$, with an average of 12:1.

\subsection{Soil Organic Carbon (SOC) and Total Nitrogen (TN) stocks}

The SOC stock for soil groups in peninsular Spain (Rodríguez-Murillo, 2001) is $66.0 \mathrm{Mg} \mathrm{ha}^{-1}$ for $\mathrm{LV}$ and soil uses is $50.5 \mathrm{Mg} \mathrm{ha}^{-1}, 42.5 \mathrm{Mg} \mathrm{ha}^{-1}$ and $39.9 \mathrm{Mg} \mathrm{ha}^{-1}$ for $\mathrm{AC}, \mathrm{V}$ and $\mathrm{OG}$, respectively; and the SOC stock for Andalucía (map of SOC content in Andalusia) are $53.2 \mathrm{Mgha}^{-1}$ and $57.3 \mathrm{Mgha}^{-1}$ for $\mathrm{LV}$ in arable crop and permanent crops, respectively (Muñoz-Rojas et al., 2012). This is in agreement with our results, which show that SOC stock is affected by LUC. The highest SOC was found under $\mathrm{AC} 1\left(332.6 \pm 28 \mathrm{Mg} \mathrm{ha}^{-1}\right)$ followed by $\mathrm{AC} 2\left(229.0 \pm 32 \mathrm{Mg} \mathrm{ha}^{-1}\right), \mathrm{V}\left(157.2 \pm 35 \mathrm{Mg} \mathrm{ha}^{-1}\right)$ and OG $\left(116.7 \pm 21 \mathrm{Mg} \mathrm{ha}^{-1}\right.$ ) (Table 3 and Fig. 4). These differences between SOC stocks for soil groups in peninsular Spain and Andalusia and the study soils are caused by soil thickness. 
We used complete soil profile for four or five horizons and Rodriguez-Murillo (2001) used descriptions of soil profiles deeper than $1 \mathrm{~m}$ and Muñoz-Rojas et al. (2012b) used control sections at $0-25,25-50$ and $50-75 \mathrm{~cm}$.

The total SOC stock for the long term (46 years) was reduced for the LUC (AC1 to V and OG) and tillage (AC1 to AC2) (Table 4). The stored SOC varies within the soil profile, with higher values in Bt horizons for $\mathrm{AC} 1, \mathrm{AC} 2$ and $\mathrm{OG}$, however, in $\mathrm{V}$ we found higher SOC in the topsoil. In this line, Novara et al. (2012) for LUC from AC to V obtained similar results and explained that this trend may be due to the mixing of the upper soil layers during soil tillage. SOC stock in the surface horizon in $\mathrm{AC} 1$ and $\mathrm{AC} 2$ varied from $39.7 \mathrm{Mg} \mathrm{ha}^{-1}$ to $48.9 \mathrm{Mg} \mathrm{ha}^{-1}$, respectively. González and Candás (2004) in clayey soils found values near $54 \mathrm{Mg} \mathrm{ha}^{-1}$ in AC. This difference of SOC stock is caused by the texture because soils included in this research were less clayey and sandier (Table 2). According to Burke et al. (1989) and Leifeld et al. (2005), high values of SOC stock in clayey soils are caused by the stabilization mechanisms of the clays in the soil. This effect can be observed in AC1 and OG, which increased the clay content with respect to $\mathrm{AC} 2$ and $\mathrm{V}$. By contrast, stored SOC was higher in the subsoil (Bt and $\mathrm{Bt} / \mathrm{C}$ horizons) in $\mathrm{AC} 1$ and $\mathrm{AC} 2$, which may be due to the translocation of $\mathrm{C}$ in the form of dissolved organic $\mathrm{C}$, soil fauna activity, and/or the effects of deep-rooting crops (Shrestha et al., 2004). On the other hand, Muñoz-Rojas et al. (2012a) found an increase of SOC for LV (14\%) after conversion from arable land to permanent crops in Andalusia (southern Spain) between 1956 and 2007, caused by the limited effect that agricultural management in permanent crops has on SOC sequestration (Smith, 2004). Moreover, Vallejo et al. (2003) indicates that the SOC stock is greater in crop pastures, which is an effect that has also been shown by Nair et al. (2009). Both authors also indicate that the potential for $\mathrm{C}$ sequestration in grass systems increases because the roots transfer large amounts of $\mathrm{C}$ into the soil slowly and contribute to the increase in the underground $\mathrm{C}$ content, which accumulates over time, thus indicating that these systems are more effective in $\mathrm{C}$ sequestration than other land uses.

In our study, TN concentrations are relatively high in areas where the SOC is high, showing a positive $\mathrm{C}: \mathrm{N}$ relation (Table 3 and Fig. 4). According to this, clay decreases SOC oxidation and could indicate a positive relationship between clay and nitrogen (Sakin et al., 2010). Some studies (Côté et al., 2000) state that the $\mathrm{N}$ mineralization decreases when the clay amount increases in the soil. We obtained similar results in LV; TN decreased when the amount of clay increased. According to the paper by McLauchlan (2006), clay concentration correlated positively with aggregate size and the rate of aggregate accumulation and the potential $\mathrm{N}$ mineralization decreases.

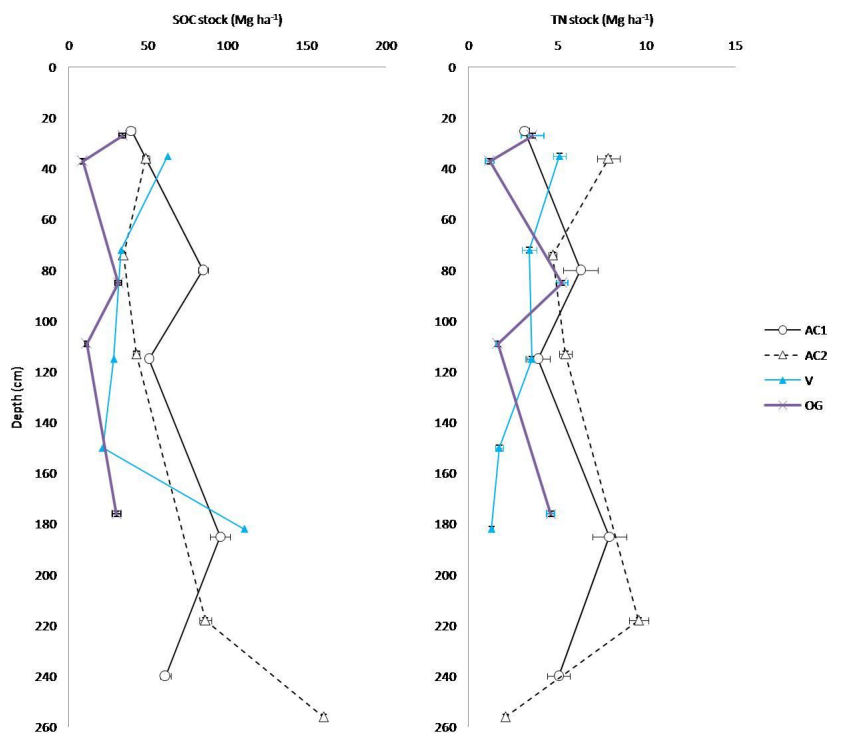

Fig. 4. Depth distribution of SOC stock and TN stock under arable crop (AC1), arable crop (AC2), vineyard (V) and olive groves (OG). Data are means $\pm \operatorname{SD}\left(n^{*}=5,7,5,10\right)$. ${ }^{*}$ Sampling size.

\subsection{The effect of LUC on SOC stock, TN and C : N ratio}

A fundamental issue has been to analyze the impact of LUC on SOC stock, TN and $\mathrm{C}: \mathrm{N}$ ratio. The change from $\mathrm{AC} 1$ to $\mathrm{AC} 2$ affected the total SOC stock reduced $31.2 \%$ and the LUC from $\mathrm{AC} 1$ to $\mathrm{V}$ and $\mathrm{OG}$ reduced $52.7 \%$ and $64.9 \%$, respectively (Table 2 and Table 3). Novara et al. (2012) for LUC from AC to V find an increase of $105 \%$. Guo and Gifford (2002) reported an increase of $18 \%$ on SOC stock for LUC from AC to plantation.

The loss of SOC stocks was influenced by management and (Table 1) AC1 had minimum tillage, with higher biomass production of plantations. As a result, the soil was always covered with vegetation, increasing OM stability, which is corroborated by Novara et al. (2012). The lowest SOC stock was in OG that reduced $64.9 \%$ with respect to AC1. A similar result was obtained by Rodriguez-Murillo (2001) and Padilla et al. (2010), the first for LUC of bushland to OG and the second for LUC of shrubland to OG. This reduction of SOC stocks from $\mathrm{AC} 1$ to $\mathrm{AC} 2, \mathrm{~V}$ and $\mathrm{OG}$, can be explained by a degraded process (vegetation losses and unsustainable soil management) resulting in continuous impoverishment in the OM content causing low soil productivity. The SOC loss in cultivated soils could be due to the OM reduced input, as well as to the reduced physical protection of soil from erosion and the increased decomposition rate as a consequence of tillage (Jordán et al., 2010; Moscatelli et al., 2007).

The $\mathrm{C}: \mathrm{N}$ ratio was higher under $\mathrm{AC} 1$ than under $\mathrm{AC} 2, \mathrm{~V}$ and OG (Table 3 and Fig. 4). This is in line with the results of Blanco-Canqui and Lal (2008) and Lou et al. (2012), which may be explained by the higher contribution of residue input under different tillage. 
Table 3. Soil organic carbon, total nitrogen and $\mathrm{C}: \mathrm{N}$ ratio stock in Calcic/Chromic Luvisol. Data are means $\pm \mathrm{SD}(n=5,7,5,10)$.

\begin{tabular}{|c|c|c|c|c|c|c|}
\hline Soil & Hor. & $\begin{array}{l}\mathrm{SOC} \\
\mathrm{Mg} \mathrm{ha}^{-1}\end{array}$ & $\begin{array}{l}\text { Total } \\
\text { SOC } \\
\mathrm{Mgha}^{-1}\end{array}$ & $\begin{array}{l}\mathrm{TN} \\
\mathrm{Mgha}^{-1}\end{array}$ & $\begin{array}{l}\text { Total } \\
\text { TN } \\
\text { Mg ha }^{-1}\end{array}$ & $\mathrm{C} / \mathrm{N}$ \\
\hline \multirow{6}{*}{$\begin{array}{l}\mathrm{AC} 1 \\
n=5^{*}\end{array}$} & Ap & $39.7 \pm 2.3$ & \multirow{6}{*}{$332.6 \pm 28$} & $3.18 \pm 0.23$ & \multirow{5}{*}{$26.41 \pm 6$} & 12.47 \\
\hline & $\mathrm{Bt}$ & $84.9 \pm 3.2$ & & $6.31 \pm 0.98$ & & 13.47 \\
\hline & $\mathrm{B} / \mathrm{C}$ & $50.9 \pm 2.1$ & & $3.92 \pm 0.65$ & & 12.96 \\
\hline & $\mathrm{C} 1$ & $95.8 \pm 6.2$ & & $7.93 \pm 0.95$ & & 12.09 \\
\hline & $\mathrm{C} 2$ & $61.3 \pm 3.2$ & & $5.07 \pm 0.65$ & & 12.07 \\
\hline & Ap & $48.9 \pm 2.4$ & & $7.87 \pm 0.63$ & \multirow{5}{*}{$29.73 \pm 8$} & 7.97 \\
\hline \multirow{4}{*}{$\begin{array}{l}\mathrm{AC} 2 \\
n=7^{*}\end{array}$} & Ap2/B & $34.7 \pm 1.6$ & \multirow{4}{*}{$229.0 \pm 32$} & $4.74 \pm 0.22$ & & 7.32 \\
\hline & $\mathrm{Bt}$ & $42.9 \pm 2.1$ & & $5.46 \pm 0.35$ & & 7.86 \\
\hline & $\mathrm{Bt} / \mathrm{C}$ & $86.4 \pm 3.8$ & & $9.57 \pm 0.54$ & & 9.03 \\
\hline & $\mathrm{C} / \mathrm{Ck}$ & $16.1 \pm 0.9$ & & $2.09 \pm 0.12$ & & 7.71 \\
\hline \multirow{6}{*}{$\begin{array}{l}\mathrm{V} \\
n=5^{*}\end{array}$} & Ap & $62.6 \pm 2.3$ & \multirow{6}{*}{$157.2 \pm 35$} & $5.12 \pm 0.36$ & \multirow{5}{*}{$15.17 \pm 3$} & 12.23 \\
\hline & $\mathrm{Bt}$ & $33.2 \pm 1.4$ & & $3.43 \pm 0.42$ & & 9.68 \\
\hline & $\mathrm{B} / \mathrm{Ck}$ & $28.6 \pm 2.3$ & & $3.57 \pm 0.38$ & & 8.00 \\
\hline & $\mathrm{C} 1$ & $21.7 \pm 1.2$ & & $1.74 \pm 0.24$ & & 12.42 \\
\hline & $\mathrm{C} 2 \mathrm{k}$ & $11.1 \pm 0.7$ & & $1.31 \pm 0.09$ & & 8.52 \\
\hline & Ap & $34.1 \pm 2.1$ & & $3.61 \pm 0.65$ & \multirow{5}{*}{$16.37 \pm 4$} & 9.44 \\
\hline \multirow{4}{*}{$\begin{array}{l}\text { OG } \\
n=10^{*}\end{array}$} & $\mathrm{Ap} / \mathrm{Bt}$ & $9.1 \pm 0.5$ & \multirow{4}{*}{$116.7 \pm 21$} & $1.21 \pm 0.25$ & & 7.47 \\
\hline & Bt1 & $31.6 \pm 2.1$ & & $5.26 \pm 0.32$ & & 6.00 \\
\hline & $\mathrm{Bt} 2 / \mathrm{BC}$ & $11.6 \pm 1.1$ & & $1.66 \pm 0.09$ & & 6.98 \\
\hline & $\mathrm{C}$ & $30.3 \pm 2.7$ & & $4.63 \pm 0.23$ & & 6.54 \\
\hline
\end{tabular}

* Size sampling.

In OG and V, SOC storage at surface depth (Ap horizon) was higher than in the rest of the profile (Fig. 3). West and Post (2002), Puget and Lal (2005), Blanco-Canqui and Lal (2008), argued that SOC stock on surface horizon is greater than in deep due to tillage and in turn increasing the physical protection of native SOC from microbial decomposition. However, $\mathrm{AC} 1$ can increase $\mathrm{C}$ inputs into surface soil by enhancing crop biomass and in turn residue return. With respect to $\mathrm{Bt}$ horizon, this relation was inverse (SOC increased in $\mathrm{Bt}$ with respect to Ap horizon). This effect can be explained by soil texture (sandy soils) and tillage, because native SOC can be reduced on the surface, which may be attributed to soluble organic compounds that can be leaching into deeper layers, increasing the soil aggregates. A similar result was obtained by Diekow et al., 2005.

Franzluebbers and Arshad (1996) and Melero et al. (2009) suggest that minimum tillage can increase SOC under longer experimental duration. Our results are in agreement with this because in AC1 increased SOC stock and the LUC and tillage for the long term (46 years) reduced SOC stock.

\subsection{Stratification of $\mathrm{SOC}, \mathrm{TN}$ and the $\mathrm{C}: \mathrm{N}$ ratio}

In all cases, the SR of SOC increased with depth with the exception of AC2 (Fig. 5), caused by the low SOC concentration in Ap2/B (transitional horizon between Ap and Bt, caused by the heavy machinery). The SR of SOC for surface to depth [SR1, SR2, SR3 and SR4] increased due to
LUC in all situations (AC2, V and OG) (Fig. 5). The LUC apparently improved soil quality because LUC caused alterations in the soil's physical and chemical properties and the soil biotic community (Caravaca et al., 2002), also, the highest carbon content in the top layer is due to carbon input from biomass residue. For degraded soils, the SR of SOC is low and occasionally reaches a value of 2.0 (Franzluebbers, 2002). Other studies have shown that SR ranges from 1.1 to 1.9 for conventional tillage (Franzluebbers, 2002; Franzluebbers et al., 2007; Hernanz et al., 2009; Sá and Lal, 2009). Higher SR of SOC is a consequence of the accumulation of surface SOC due to straw soil surface coverage and root distribution change.

The SR of TN showed a similar trend in the SR of SOC. The SR of $\mathrm{C}: \mathrm{N}$ ratio increased in depth, in AC1 and OG, but had no significant differences with respect to soil use. This can be explained by a higher contribution of residue relative to root inputs leading a higher soil $\mathrm{C}: \mathrm{N}$ ratio (Puget and Lal, 2005). Under $\mathrm{AC} 1$, the residue input could have been concentrated on the surface due to straw soil surface coverage, so the soil $\mathrm{C}: \mathrm{N}$ ratio was stratified. This slight change in $\mathrm{C}: \mathrm{N}$ ratio suggests the decomposition degree of SOC decreases toward the surface (Lou et al., 2012). This suggests little effect in the LUC and tillage system on the carbon accumulation in the soil. Balesdent and Balabane (1996) do not find any significant differences in SR, in a Geauga farm (Ohio). In $\mathrm{AC} 2, \mathrm{~V}$ and $\mathrm{OG}$ had ensured the supply of OM from the 


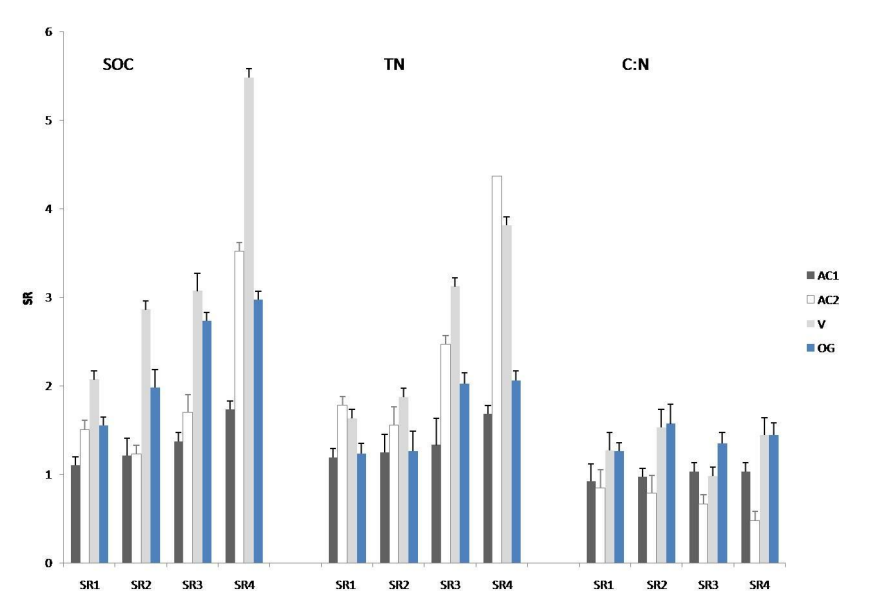

Fig. 5. Stratification ratios (SR) of SOC concentrations, TN concentrations and $\mathrm{C}: \mathrm{N}$ ratios under arable crop ( $\mathrm{AC} 1)$, arable crop (AC2), vineyard (V) and olive groves (OG). Data are means \pm SD $\left(n^{*}=5,7,5,10\right) .{ }^{*}$ Sampling size.

surface horizons to a deeper horizon, which suggested an accumulation of carbon in the profile under these systems.

The higher SRs observed at OG and V, compared to AC1 and $\mathrm{A} 2$, was probably due to the presence of a herb layer and the low herbicide applications. The important role of a herb layer, in both protecting soil from the erosion process (Novara et al., 2011) and contributing to SOM content, might explain the similarity among the characteristics of the OG and $\mathrm{V}$.

\subsection{Limitations to SRs method}

Many authors had applied the SR methodology (Franzluebbers, 2002), in most cases using control sections (MuñozRojas et al., 2012b), in other cases using the entire soil profile (Corral-Fernández et al., 2013). When control sections are used, similar soil thickness can be compared between them, however, if the entire soil profile were used especially to study land uses and/or management changes for a long time, these comparisons can be more complicated.

We can observe in this study that the SOC, TN and C:N ratio decreased for LUC and management types (Table 2); in contrast the SRs increased (Fig. 4) when land uses and management changes were applied, and this situation may seem contradictory because this decrease of SOC, TN and $\mathrm{C}: \mathrm{N}$ ratio should involve a decrease in the SRs index. These contradictory results are due to SR definition (a soil property on the soil surface divided by the same property at a lower depth) for these cases: SOC, TN and $\mathrm{C}: \mathrm{N}$ ratio.
The first consideration to the method is a soil thickness decrease for the LUC from AC1 to $\mathrm{V}$ and OG (Table 2 and Fig. 1), however, the surface horizon thickness increased, associated with the new land uses (new mechanized equipment-heavy machinery). The second consideration is caused by a subsurface horizon thickness that decreased in depth; these factors analyzed together explain the SRs increased. The third issue is caused by the LUC for long-term favors promotes the development of new diagnostic horizon, e.g. AC1 [Bt $(25-80 \mathrm{~cm})], \mathrm{AC} 2$ [Bt $(74-113 \mathrm{~cm})$ and $\mathrm{Bt} / \mathrm{C}$ $(113-218 \mathrm{~cm})]$ and $\mathrm{OG}$ [Bt1 $(37-85 \mathrm{~cm})$ and $\mathrm{Bt} 2 / \mathrm{BC}(85-$ $109 \mathrm{~cm}$ ). If we integrated these horizons, the subsurface horizon thickness increased in depth and this new scenario reduced the SRs for LUC.

\section{Conclusions}

The LUC has a negative impact on the soil, reducing the SOC and TN stocks. The stored SOC varies along the profile, with higher values in the Ap horizon (caused by the mixing of the upper soil layers during soil tillage) and $\mathrm{Bt}$ horizons (due to the translocation of $\mathrm{C}$ in the form of dissolved organic $\mathrm{C}$, soil fauna activity, and/or the effects of deep-rooting crops). TN concentrations were high in areas where the SOC was high, showing a positive $\mathrm{C}: \mathrm{N}$ relation.

The reduction of SOC by LUC can be explained by a degraded process (due to vegetation losses and unsustainable soil management, which result in progressive impoverishment in the SOM content, causing low productivity, which derived in unsuitable chemical properties) and by the reduced input of OM in cultivated soils, which reduced physical protection of soil and increased water erosion. However, with respect to the SRs, 46 years of LUC had a positive effect in the soil, increasing the SR (in V and OG) of SOC, TN and $\mathrm{C}: \mathrm{N}$ ratio, caused by the reduction in depth of the SOC and TN.

In general, the LUC reduces the SOC and TN concentrations and by contrast increases the SRs index. The use of entire profiles is necessary in these soils because in temperate climates, large amounts of SOC may be stored in subsoil horizons. This is essential in LUC because SOC can be transported to deeper soil horizons, contributing to the subsoil C storage.

Acknowledgements. The authors wishes to thank the two anonymous referees an the editor for their helpful comments.

Edited by: A. Cerdà 


\section{References}

Acosta-Martínez, V., Klose, S., and Zobeck, T. M.: Enzime activities in semiarid soils under conservation reserve program, native rangeland, and cropland, J. Plant Nutr. Soil Sci., 166, 699-707, 2003.

Albretch, A. and Kandji, S.: Carbon sequestration in tropical agroforestry systems. Agric. Ecosyst. Environ., 99, 15-27, 2003.

Balesdent, J. and Balabane, M.: Major contribution of roots to soil carbon storage inferred from maize cultivated soils, Soil Biol. Biochem., 28, 1261-1263, 1996.

Bakker, M. M., Govers, G., Kosmas, C., Vanacker, V., Oost, K., and Rounsevell, M.: Soil erosion as a driver of land-use change, Agric. Ecosyst. Environ., 105, 467-481, 2005.

Blanco-Canqui, H. and Lal, R.: No-tillage and soil-profile carbon sequestration: an on farm assessment, Soil Sci. Soc. Am. J., 72, 693-701, 2008.

Blake, G. R. and Hartge, K. H.: Bulk density, in: Methods of Soil Analysis: Part 1, Physical and Mineralogical Methods, edited by: Klute, A., 2 Edn. American Society of Agronomy, Madison, WI, 1986.

Brady, C. and Weil R. R.: The nature and properties of soils, 14 Edn., Pearson Prentice hall. Upper Saddle River, New Jersey Columbus, Ohia, USA, 2008.

Bremner, J. M.: Total nitrogen, in: Methods of Soil Analysis: Chemical Methods, Soil Science Society of America, edited by: Sparks, D. L., Madison, WI, 1085-1086, 1996.

Burke, I., Yonker, C., Parton, W., Cole, C., Flach, K., and Schimel, D.: Texture, climate, and cultivation effects on soil organic matter content in U.S. grassland soils, Soil Sci. Soc. Am. J., 53, 800805, 1989.

Caravaca, F., Masciandaro, G., and Ceccanti, B.: Land use in relation to chemical and biochemical properties in semiarid Mediterranean environment, Soil Till. Res., 68, 23-30, 2002.

Cerdà, A., Lavee, H., Romero-Díaz, A., Hooke, J., and Montanarella, L.: Preface, Land Degrad. Dev., 21, 71-74, 2010.

Conant, R. T. and Paustian, K.: Potential soil carbon sequestration in overgrazed grassland ecosystems, Global Biogeochem. Cy., 16, 90, 2002.

Corral-Fernández, R., Parras-Alcántara, L., and Lozano-García, B.: Stratification ratio of soil organic $\mathrm{C}, \mathrm{N}$ and $\mathrm{C}: \mathrm{N}$ in Mediterranean evergreen oak woodland with conventional and organic tillage, Agric. Ecosyst. Environ., 164, 252-259, 2013.

Côté, L., Brown, S., Paré, D., Fyles, J., and Bauhus, J.: Dynamics of carbon and nitrogen mineralization in relation to stand type, stand age and soil texture in the boreal mixedwood, Soil Biol. Biochem., 32, 1079-1090, 2000.

Diekow, J., Mielniczuk, J., Knicker, H., Bayer, C., Dick, D. P., and Kögel-Knabner, I.: Soil C and N stocks as affected by cropping systems and nitrogen fertilisation in a southern Brazil Acrisol managed under no-tillage for 17 years, Soil Till. Res., 81, 87-95, 2005.

Don, A., Schumacher, J., Scherer-Lorenzen, M., Scholten, T., and Schulze, E.: Spatial and vertical variation of soil carbon at two grassland sites. Implications for measuring soil carbon stocks, Geoderma, 141, 272-282, 2007.

Eaton, J. M., McGoff, N. M., Byrne, K. A., Leahy, P., and Kiely, G.: Land cover change and soil organic $\mathrm{C}$ stocks in the Republic of Ireland 1851-2000, Climatic Change, 91, 317-334, 2008.
Franzluebbers, A. J.: Soil organic matter stratification ratio as an indicator of soil quality, Soil Till. Res., 66, 95-106, 2002.

Franzluebbers, A. J. and Arshad, M. A.: Soil organic matter pools during early adoption of conservation tillage in northwestern Canada, Soil Sci. Soc. Am. J., 60, 1422-1427, 1996.

Gallardo, A., Rodríguez-Saucedo, J., Covelo, F., and FernándezAles, R.: Soil Nitrogen heterogeneity in dehesa ecosystem, Plant Soil, 222, 71-82, 2000.

González, J. and Candás, M.: Materia orgánica de suelos bajo encinas. Mineralización de carbono y nitrógeno, Invest. Agrar: Sist Recur For. Fuera de serie, 75-83, 2004.

González-Sánchez, E. J., Ordóñez-Fernández, R., CarbonellBojollo, R., Veroz-González, O., and Gil-Ribes, J. A.: Metaanalysis on atmospheric carbon capture in Spain through the use of conservation agriculture, Catena, 122, 52-60, 2012.

Grüneberg, E., Schöning, I., Kalko, E. K. V., and Weisser, W. W.: Regional organic carbon stock variability: A comparison between depth increments and soil horizons, Geoderma 155, 426433, 2010.

Guitián, F. and Carballas, T.: Técnicas de Análisis de Suelos. Edit. Picro Sacro, Santiago de Compostella, España, 1976.

Guo, L. B. and Gifford, R. M.: Soil carbon stocks and land use change: a meta analysis, Glob. Change Biol., 8, 345-360, 2002.

Hernanz, J. L., Sanchez-Giron, V., and Navarrete, L.: Soil carbon sequestration and stratification in a cereal/leguminous crop rotation with three tillage systems in semiarid conditions, Agric. Ecosyst. Environ., 133, 114-122, 2009.

Houghton, R.A .: Why are estimates of the terrestrial carbon balance so different? Global Change Biol. 9, 500-509, 2003.

IPCC.: Climate change 2007: the physical science basis, Cambridge University Press: Cambridge/New York, NY, 2007.

IUSS Working Group WRB.: World reference base for soil resources 2006, World Soil Resources Reports No. 103. FAO, Rome.

Jobbágy, E. G. and Jackson, R. B.: The vertical distribution of soil organic carbon and its relation to climate and vegetation, Ecol. Appl. 104, 423-436, 2000.

Johnson, J. M., Franzluebbers, A. J., Lachnicht-Weyers, S., and Reicosky, D. C.: Agricultural opportunities to mitigate greenhouse gas emissions, Environ. Pollut., 150, 107-124, 2007.

Jordán, A., Zavala, L. M., and Gil, J.: Effects of mulching on soil physical properties and runoff under semi-arid conditions, Catena, 81, 77-85, 2010.

Lal, R.: Residue management, conservation tillage and soil restoration for mitigating greenhouse effect by $\mathrm{CO}_{2}$-enrichment, Soil Till. Res., 43, 81-107, 1997.

Lal, R.: Soil erosion and the global carbon budget, Environment International 29, 437-450, 2003.

Lal, R., Kimble, J., and Stewart, B. A.: World Soils as a or sink for radio-active gases, in: Soil management and greenhouse effect, edited by: Jorgensen, B. B., Lewis, London, 1-7, 1995.

Lal, R., Delgado, J. A., Groffman, P. M., Millar, N., Dell, C., and Rotz, A.: Management to mitigate and adapt to climate change, J. Soil Water Conserv., 66, 276-285, 2011.

Leifeld, J., Bassin, S., and Fuhrer, J.: Carbon Stocks in Swiss agricultural soils predicted by Land-use. Soil characteristics and altitude, Agric. Ecosyst. Environ., 105, 255-266, 2005.

Lorenz, K. and Lal, R.: The depth distribution of organic soil carbon in relation to land use and management and the potential of car- 
bon sequestration in subsoil horizons, Adv. Agron., 88, 35-66, 2005.

Lou, Y., Xu, M., Chen, X., He, X., and Zhao, K.: Stratification of soil organic $\mathrm{C}, \mathrm{N}$ and $\mathrm{C}: \mathrm{N}$ ratio as affected by conservation tillage in two maize fields of China, Catena 95, 124-130, 2012.

Lozano-García, B., Parras-Alcántara, L., and Del Toro, M.: The effects of agricultural management with oil mill by-products on surface soil properties, runoff and soil losses in southern Spain, Catena, 85, 187-193, 2011.

Lozano-García, B. and Parras-Alcántara, L.: Short-term effects of olive mill by-products on soil organic carbon, total $\mathrm{N}, \mathrm{C}: \mathrm{N}$ ratio and stratification ratios in a Mediterranean olive grove, Agric. Ecosyst. Environ., 165, 68-73, 2013.

McKenzie, N. J. and Austin, M. P.: A quantitative Australian approach to medium and small scale surveys based on soil stratigraphy and environmental correlation, Geoderma 57, 329-355, 1993.

McLauchlan, K. K.: Effect of soil texture on soil carbon and nitrogen dynamic after cessation of agriculture, Geoderma, 136, 289-299, 2006.

Melero, S., López-Garrido, R., Murillo, J. M., and Moreno, F.: Conservation tillage: Short- and long-term effects on soil carbon fractions and enzymatic activities under Mediterranean conditions, Soil Till. Res., 104, 292-298, 2009.

Miller, A. J., Amundson, R., Burke, I. C., and Yonker, C.: The effect of climate and cultivation on soil organic $\mathrm{C}$ and $\mathrm{N}$, Biogeochemistry, 67, 57-72, 2004.

Moscatelli, M. C., Di Tizio, A., Marinari, S., and Grego, S.: Microbial indicators related to soil carbon in Mediterranean land use systems, Soil Till. Res., 97, 51-59, 2007.

Muñoz-Rojas, M., Jordán, A., Zavala, L. M., De la Rosa, D., AbdElmabod, S. K., and Anaya-Romero, M.: Impact of land use and land cover changes on organic carbon stocks in Mediterranean soils (1956-2007), Land Degrad. Dev., doi:10.1002/ldr.2194, 2012a.

Muñoz-Rojas, M., Jordán, A., Zavala, L. M., De la Rosa, D., AbdElmabod, S. K., and Anaya-Romero, M.: Organic carbon stocks in Mediterranean soil types under different land uses (Southern Spain), Solid Earth, 3, 375-386, doi:10.5194/se-3-375-2012, 2012b.

Nair, P. K., Kumar, B., and Nair, D.: Agroforestry as a strategy for carbon sequestration, J. Soil Sci. Plant Nut., 172, 10-23, 2009.

Novara, A., Gristina, L., Saladino, S. S., Santoro, A., and Cerdá, A.: Soil erosion assessment on tillage and alternative soil managements in a Sicilian vineyard, Soil Till. Res., 117, 140-147, 2011

Novara, A., La Mantia, T., Barbera, V., and Gristina, L.: Paired-site approach for studying soil organic carbon dynamics in a Mediterranean semiarid environment, Catena, 89, 1-7, 2012.

Ouédraogo, E., Mando, A., and Stroosnijder, L.: Effects of tillage, organic resources and nitrogen fertiliser on soil carbon dynamics and crop nitrogen uptake in semi-arid West Africa, Soil Till. Res., 91, 57-67, 2006.

Padilla, F. M., Vidal, B., Sánchez, J., Pugnaire, F. I.: Land-use changes and carbon sequestration through the twentieth century in a Mediterranean mountain ecosystem: implications for land management, J. Environ. Manage., 91, 2688-2695, 2010.

Powlson, D. S., Whitmore, A. P., and Goulding, K. W. T.: Soil C sequestration to mitigate climate change: a critical re-examination to identify the true and the false, Eur. J. Soil Sci., 62, 42-55, 2011.

Puget, P. and Lal, R.: Soil organic carbon and nitrogen in a Mollisol in central Ohio as affected by tillage and land use, Soil Till. Res., 80, 201-213, 2005.

Rodríguez-Murillo, J. C.: Organic carbon content under different types of land use and soil in peninsular Spain, Biol. Fertil. Soils, 33, 53-61, 2001.

Ruiz, J. D., Pariente, S., Romero, A., and Martínez, J. F.: Variability of relationships between soil organic carbon and some soil properties in Mediterranean rangelands under different climatic conditions (South of Spain), Catena, 94, 17-25, 2012.

Sá, J. C. M., Cerri, C. C., Dick, W. A., Lal, R., Venske-Filho, S. P., Piccolo, M. C., and Feigl, B. E.: Organic matter dynamics and carbon sequestration rates for a tillage chronosequence in a Brazilian Oxisol, Soil Sci. Soc. Am. J., 65, 1486-1499, 2001.

Sá, J. C. M. and Lal, R.: Stratification ratio of soil organic matter pools as an indicator of carbon sequestration in a tillage chronosequence on a Brazilian Oxisol, Soil Till. Res., 103, 4656, 2009.

Sakin, E., Deliboran, A., Sakin, E. D., and Tutar, E.: Organic and inorganic carbon stock and balance of Adana city soils in Turkey, African J. Agric. Res., 5, 2737-2743, 2010.

Shrestha, B.M., Sitaula, B.K., Singh, B.R., Bajracharya, R.M.: Soil organic carbon stocks in soil aggregates under different land use systems in Nepal. Nutr. Cycl. Agroecosys. 70, 201-213, 2004.

Smith, P., Powlson, D. S., Smith, J. U., Fullon, P., and Coleman, K.: Meeting Europe's climate change commitments: quantitative estimates of the potential for carbon mitigation by agriculture, Glob. Change Biol., 6, 525-539, 2000.

Smith, P.: C sequestration in croplands: the potential in Europe and the global context, Europ. J. Agronomy, 20, 229-236, 2004.

Smith, P.: Land use change and soil organic carbon dynamics, Nutr. Cycl. Agroecosys., 81, 169-178, 2008.

Sombrero, A. and de Benito, A.: Carbon accumulation in soil. Tenyear study of conservation tillage and crop rotation in a semi-arid area of Castile-Leon, Spain, Soil Till. Res., 107, 64-70, 2010.

SPSS Inc.: SPSS for windows, Version 13.0. Chicago, SPSS Inc., 2004.

USDA.: Soil survey laboratory methods manual, Soil survey investigation report No. 42, Version 4.0, USDA-NCRS, Lincoln, NE, 2004.

Vallejo, R., Díaz Fierro, F., and De la Rosa, D.: Impactos sobre los recursos edáficos. In Impactos del cambio climático en España, MMA eds, Madrid, 2003.

VandenBygaart, A. J.: Monitoring soil organic carbon stock changes in agricultural landscapes: issues and a proposed approach, Can. J. Soil Sci., 86, 451-463, 2006.

Van Oost, K., Govers, G., Quine, T. A., Heckrath, G., Olesen, J. E., De Gryze, S., and Merckx, R.: Landscape-scale modeling of carbon cycling under the impact of soil redistribution: the role of tillage erosion, Global Biogeochem. Cy., 19, GB4014, doi:10.1029/2005GB002471, 2005.

Walkley, A. and Black, I. A.: An examination of the Degtjareff method for determining soil O.M. and a proposed modification of the chromic acid titration method, Soil Sci., 37, 29-38, 1934.

Wang, W. J. and Dalal, R. C.: Carbon inventory for a cereal cropping system under contrasting tillage. Nitrogen fertilisation and stubble management practices, Soil Till. Res., 91, 68-74, 2006. 
Watson, R. T., Noble, I. R., Bolin, B., Ravindramath, N. H., Verardo, D. J., and Dokken, D.J.: Land-use, Land-use change, and Forestry (A Special Report of the IPCC). Cambridge University Press, Cambridge, 2000.

West, T. O. and Post, W. M.: Soil organic carbon sequestration rates by tillage and crop rotation: a global data analysis, Soil Sci. Soc. Am. J., 66, 1930-1946, 2002.

Wright, A. L., Hons, F. M., Lemon, R. G., McFarland, M. L., and Nichols, R. L.: Stratification of nutrients in soil for different tillage regimes and cotton rotations, Soil Till. Res., 96, 19-27, 2007.

Xu, M., Lou, Y., Sun, X., Wang, W., Baniyamuddin, M., and Zhao, K.: Soil organic carbon active fractions as early indicators for total carbon change under straw incorporation, Biol. Fert. Soils, 47, 745-752, 2011.
Yamashita, T., Feiner, H., Bettina, J., Helfrich, M., and Ludwig, B.: Organic matter in density fractions of water-stable aggregates in silty soils: effect of land use, Soil Biol. Biochem., 38, 32223234, 2006.

Zhang, T., Wang, Y., Wang, X., Wang, Q., and Han, J.: Organic carbon and nitrogen stocks in reed meadow soils converted to alfalfa fields, Soil Till. Res., 105, 143-148, 2009.

Zdruli, P., Kapur, S., and Çelik, I.: Soils of the Mediterranean Region. Their characteristics, management and sustainable us, in: Sustainable land management learning from the past for the future, edited by: Kapur, S., Eswaran, H., Blum, W. E. H., SpringerVerlag: Berlin, 2011. 